Marquette University

e-Publications@Marquette

Education Faculty Research and Publications

Education, College of

4-1-2016

Screening for Significant Behavior Problems in

Diverse Young Children Living in Poverty

Sara E. Harris

Marquette University

Robert A. Fox

Marquette University, robert.fox@marquette.edu

Casey A. Holtz

Marquette University

Accepted version. Journal of Child and Family Studies, Vol. 25, No. 4 (April 2016): 1076-1085. DOI.

(C) 2016 Springer International Publishing AG. Used with permission. 


\title{
Screening for Significant Behavior Problems in Diverse Young Children Living in Poverty
}

\author{
Sara E. Harris \\ Department of Counselor Education and Counseling Psychology, \\ Marquette University, \\ Milwaukee, WI \\ Robert A. Fox \\ Department of Counselor Education and Counseling Psychology, \\ Marquette University, \\ Milwaukee, WI \\ Casey A. Holtz \\ Department of Psychology, Wisconsin Lutheran College \\ Milwaukee, WI
}

\section{Acknowledgements}

This research was supported in part by grants from Aurora Health Care Better Together Fund, Brighter Futures of Milwaukee, Charles D. Jacobus Family Foundation, Exchange Clubs of Greater Milwaukee Charitable Foundation, Greater Milwaukee Foundation, Helen Bader Foundation, Hearst Foundation, Roger and Cindy Schaus Family, United Way and the Zilber Family Foundation. 
NOT THE PUBLISHED VERSION; this is the author's final, peer-reviewed manuscript. The published version may be accessed by following the link in the citation at the bottom of the page.

\section{Abstract}

The development and use of first line screening instruments is an essential first step in assessing behavior disorders in very young children. The Early Childhood Behavior Screen (ECBS) is a parent-report measure for behavior disorders and is normed on young children ( 1 to 5 years old) living in poverty. The current study presents psychometric support for the discriminative validity of the ECBS's 10-item Challenging Behavior Scale (CBS) as a first-line screener for externalizing behavior problems for preschool aged-children in poverty. The study's sample included 673 participants ( $M$ age years $=2.81 ; 63.2 \%$ male; $65.8 \%$ African American) that all met the federal definitional standard for living in poverty. A confirmatory factor analysis was run to provide support for the ECBS factor structure. Receiver operating characteristics (ROC) curve analyses were used to test the CBS's ability to distinguish between 428 clinic-referred children and 245 nonclinic-referred children. Results showed an acceptable fit model for the ECBS, providing further evidence of its construct validity. Optimal cut-scores by child age derived from the ROC curve analyses were provided with corresponding levels of sensitivity, specificity, and positive and negative predictive values. Sensitivity rates for cut scores ranged from .76 - .83 and specificity rates ranged from .88-.95. Acceptable test-retest reliability and good internal consistency also was observed. The CBS quickly identifies young children from low-income, urban, diverse populations that may be at-risk for developing significant behavior disorders and should be considered by health care professionals who work with very young children.

Key words: early childhood, externalizing behaviors, assessment, poverty

\section{Introduction}

The prevalence of behavior disorders in preschool children is similar to school-aged children (Egger \& Arnold, 2006) and can remain stable well beyond the preschool years (Fanti \& Henrich, 2010; see review by Poulou, 2015). Poverty is one important contextual factor that places younger children at greater risk of developing behavior problems (van Oort, van der Ende, Wadsworth, Verhulst, \& Achenbach, 2011). Research has shown that behavior problems among children in poverty can range between $17 \%$ (Holtz, Fox, \& Meurer, 2015) to over 52\% (Feil, Walker, Severson, \& Ball, 2000), compared to $10-15 \%$ for children in general (Campbell, 2002). Importantly, males, individuals from low-income families, and children raised by mothers without high school completion were found to be at 
increased risk for highly stable externalizing behavioral problems (Cote, Vaillancourt, LeBlanc, Nagin \& Tremblay, 2006; Fanti \& Henrich, 2010). Thus, instruments that are developed for this high-risk population are needed to help aid in early intervention. Clearly, the earlier these children can be identified, the sooner developmentallyappropriate early intervention services can be delivered to reduce their behavior problems (Harris, Fox, \& Love, 2015).

Unfortunately, the use of relatively lengthy assessment instruments to identify these children is unlikely to occur in busy school and health care settings (Glascoe, 2005). Although teacherreferral of children with externalizing behaviors has been recommended as a first step in a multi-tiered assessment system (Feeney-Kettler, Kratochwill, Kaiser, Hemmeter \& Kettler, 2010; TylerMerrick \& Church, 2013), very young children often are not enrolled in formal school programs. Consequently, their initial contact with professionals will likely be one of their health care providers (e.g., pediatrician, family practice physician, public health nurse) or a Head Start teacher. In order to identify very young children with significant behavior problems, particularly those living in poverty, first-line screeners have been recommended to quickly and efficiently identify children who may be in need of more intensive follow-up services (Carter, Briggs-Gowan \& Davis, 2004).

Currently, there are very few measures that are normed for this very young, at-risk population that can be quickly administered, scored and interpreted. For example, the Child Behavior Checklist (CBCL; Achenbach \& Rescorla, 2000) is often referred to as the gold standard for parent-report instruments. However, its length, complex scoring and interpretation for novice administrators (e.g., teachers, pediatricians) make it impractical in many settings as a screening device where these children are found. Even shorter instruments such as the well-established Eyberg Child Behavior Inventory (ECBI; Eyberg \& Pincus, 1999) includes 36 items with two rating scales for each item and was designed for children from two to 16 years of age. Consequently, a number of the items are not appropriate for younger children. Also, less educated parents have difficulty with some of the ECBI vocabulary (e.g., dawdles), do not make full use of the sevenpoint Likert scale, and take significant time to complete the scale even 
when the items are read for them. Also the use of this instrument with diverse populations has only recently begun to be explored (Butler, 2013). Finally, most available instruments include only limited samples of very young children living in poverty, if any at all.

Compounding this assessment issue, disparities in the delivery of mental health services in diverse low income areas, have been well documented (e.g., Bringewatt \& Gershoff, 2010; Stevens, Seid, Pickering, \& Tsai, 2010). Thus, many young children who are at-risk for developing serious behavior problems, particularly those from lowincome families, may not be identified until they reach school age when their behavior problems become more intractable and challenging to resolve.

The Early Childhood Behavior Screen (ECBS; Holtz \& Fox, 2012) is a 20 -item parent-report screening instrument developed specifically for very young children ( 1 to 5 -years-old) from low-socioeconomic backgrounds. The initial study on the development of the ECBS empirically identified two factors, one including challenging behaviors and a second addressing prosocial behavior. For the 10-item Challenging Behavior Scale (CBS), initial construct validity was established by examining how well it correlated with Eyberg Child Behavior Inventory (ECBI; Eyberg \& Pincus, 1999); a positive correlation was found $(r=.74, p<.01)$. Internal consistency for the initial representative and diverse sample of 439 young children from a large urban area was .87 (the 10 prosocial items had a coefficient alpha of .92). Holtz \& Fox (2012) acknowledged that their study was the first step in the development of the ECBS.

The first goal of the present study was to provide further evidence of the construct validity for the ECBS by conducting a Confirmatory Factor Analysis (CFA) using a sample of clinicallyreferred young children to determine how well the data fit the original two-factor structure identified with the non-clinical sample. The second, and primary goal of the study, was to determine how well the CBS could discriminate between a sample of clinically-referred children and non-clinical children to assess the utility of this measure as a screening instrument in a low-income sample. The prosocial subscale of the ECBS was not examined in this analysis because it is not used to 
screen for children with behavior problems, but rather to identify clinically relevant strengths within children to be strengthened further through intervention work.

\section{Method}

\section{Participants}

The participants were 673 children ranging in age from 1 to 5 years old ( $M$ age years $=2.81 ; S D=1.12$ ). Data for the clinical sample $(n=428)$ were collected at a community clinic developed specifically to provide in-home, mental health services for young children living in poverty (Fox, Keller, Grede, \& Bartosz, 2007) who were consecutively referred by over 75 community agencies, individual health care providers and parents for behavioral concerns (e.g., aggression, hyperactivity, oppositional behaviors, property destruction, self-injury). The initial intake evaluation included a structured diagnostic interview and an assessment of the child's behavior using the ECBS. The most common diagnoses among the clinical sample included Disruptive Behavior Disorder ( $n=174 ; 40.6 \%)$, Oppositional Defiant Disorder $(n=83 ; 19.4 \%)$, Adjustment Disorder $(n=45$; $10.5 \%)$, and Attention Deficit Hyperactivity Disorder $(n=16 ; 3.7 \%)$. Data for the non-clinical sample $(n=245)$ was collected during routine checkups at a community health clinic. Children were not included in the non-clinical sample if a parent reported both a significant concern with the child's behavior, and if the child's ECBI score was in the clinically elevated range; however, these parents were provided information regarding where their child could receive a more intensive evaluation and mental health services, if needed. Children with prior Autism diagnoses, severe to profound intellectual disabilities, or ongoing serious medical concerns were not included in the study. Additionally, children who did not meet the federal definition for poverty, which required that they were receiving public assistance, were excluded from the current study. Demographic information for the clinical and non-clinical groups is summarized in Table 1. 
NOT THE PUBLISHED VERSION; this is the author's final, peer-reviewed manuscript. The published version may be accessed by following the link in the citation at the bottom of the page.

\section{Procedures}

The Institutional Review Board at a Midwestern university granted approval for data collection for the sample of children referred to a community clinic. Permission to use data for the original measure that was normed on a non-clinical sample of children also was obtained. All parents who completed the ECBS were informed that participation was voluntary and signed informed consent prior to participation. Graduate students and master-level, licensed clinicians completed the diagnostic clinical interviews and ECBS with the children's primary guardian. All cases were supervised and reviewed by a licensed psychologist.

\section{Measures}

Intake Form (IF). The IF was used to collect demographic information about the referred child (e.g., gender, date of birth, siblings) and the family and others who were living in the child's home and/or providing care for the child. The IF also was used to collect information about the child's birth history, developmental milestones, current health, previous involvement with child protective services, and medications. In addition, the IF helped determine the frequency and nature of the child's referral concerns, possible contributing factors, and how the caregivers were presently responding to the referral concerns.

Early Childhood Behavior Screen (ECBS). The ECBS (Holtz \& Fox, 2012) is a 20-item self-report screening instrument developed specifically for very young children in poverty. The ECBS items were written at a 3.9 reading grade level and included 10 prosocial behavior items (e.g., "listens to you," "shares toys") and 10 challenging behavior items (e.g., "hits others," "has temper tantrums"). The scale instructions asked caregivers to rate each item according to their perception of their child's behavior over the past week based on a three-point scale ( $1=$ rarely/never, $2=$ sometimes, or $3=$ almost always/always). Scores on the Challenging Behavior scale (CBS) can range from 10 to 30, with higher scores indicating greater frequency of challenging behaviors. Scores on the Prosocial Behavior scale (PBS) 
NOT THE PUBLISHED VERSION; this is the author's final, peer-reviewed manuscript. The published version may be accessed by following the link in the citation at the bottom of the page.

ranged from 10 to 30 , with higher scores indicating a greater frequency of positive behaviors.

\section{ECBS Reliability}

The internal consistency of the CBS was calculated using coefficient alpha for the clinical sample. The coefficient alpha for the clinical sample was .91 and the average inter-item correlation was .50. Testretest reliability was gathered at intake and again four to eight weeks during parent-child treatment. A satisfactory test-retest reliability of .76 was observed $(p<.001)$ for the CBS. The internal consistency for the PBS was .87 and the average inter-item correlation was .41.

\section{Results}

\section{Confirmatory Factor Analysis (CFA)}

The CFA was conducted on the clinical sample to confirm how well the data fit the original two-factor structure identified by the nonclinical sample (see Figure 1). Correlations, means, and standard deviations of the items can be found in Table 2 . Three standard measures of model fit were used: the Tuker-Lewis Index (TLI), the Comparative Fit Index (CFI), and the root mean square error of approximation (RMSEA). Bentler and Bonett (1980) established .90 for the TLI and CFI and Brown \& Cudeck (1993) established a RMSEA of $<.08$, all as indicators of a reasonable fit model. For the present CFA, the model estimated the relations between the original ECBS two factors: challenging behaviors and prosocial behaviors. Weighted Least Squares Mean and Variance (WLSMV) estimation was used and the results were: $X^{2}(169)=448.918, p<.001$, RMSEA $=.062(C I=$ $0.055,0.069)$, CFI $=0.927$ and TLI $=.917$. The unstandardized and standardized parameter estimates and standard errors can be found in Table 3. Although the $X^{2}$ was significant, this is not uncommon for models with large sample sizes, and taken as a whole when examining all measures of fit, the model is considered to have an acceptable fit. 
NOT THE PUBLISHED VERSION; this is the author's final, peer-reviewed manuscript. The published version may be accessed by following the link in the citation at the bottom of the page.

\section{Demographic Variables and the CBS}

Because age and gender may influence scores on externalizing behavior measures, ANOVA tests were conducted to examine the effect these variables had on CBS scores. Separate analyses were conducted for the clinical and non-clinical groups, and significance levels were reported to allow for an examination of experiment wise error rate. Descriptive data for the clinical and non-clinical samples CBS scores by gender and age are provided in Table 4 . The gender main effect in the clinical group was not significant, $F(1,418)=.89, p$ $=.346, \underset{p}{2}=.002$. There was, however, a significant effect for age, $F$ $(4,418)=3.04, p=.017,{ }_{p}^{2}=.028$. Post hoc comparisons using the Tukey HSD test did not reveal significant differences for any of the age groups. This suggests that while age may have an effect on the CBS scores in the clinical sample, the effect was small. For children in the clinical group, no significant interaction effect was found between gender and age $(p>.05)$. For children in the non-clinical group, the gender main effects was significant, $F(1,235)=5.48, p=.020, \quad{ }_{p}^{2}=$ .023. There also was a main effect for age $F(4,235)=10.22, p<$ $.001, \underset{p}{2}=.148$. Post hoc comparisons using the Tukey HSD test indicated that the mean scores for 1 year olds $(M=16.46, S D=3.82)$ and 2 year olds $(M=17.28, S D=3.24)$ were significantly different than the mean scores for 4 year olds $(M=14.35, S D=3.06)$ and 5 year olds $(M=12.95, S D=2.50)$. Additionally, 3 year olds $(M=$ $14.83, \mathrm{SD}=2.88$ ) had significantly lower mean scores than 2 year olds $(M=17.28, S D=3.24)$, but did not significantly differ from any other age group. In general, younger children scored higher on the CBS than their slightly older counterparts, with 2 year olds having the highest mean score. No significant interaction effect was found between gender and age $(p>.05)$. Figure 2 illustrates the relation of the CBS total scores across child age in the clinical and non-clinical groups. 
NOT THE PUBLISHED VERSION; this is the author's final, peer-reviewed manuscript. The published version may be accessed by following the link in the citation at the bottom of the page.

\section{ROC Curve Analysis}

Age was a significant predictor of CBS scores in both samples. Consequently, ROC curve analyses were conducted separately for each age group. Results for each ROC curve analysis and their corresponding specificity, sensitivity, and positive and negative predicative values are provided in Table 5. The ROC curves' areas under the curve were significant at the $p<.001$ level and ranged from .87 to .97 , indicating good to excellent discrimination across age groups. In other words, there was $87 \%$ to $97 \%$ likelihood that a randomly selected a child in the clinical group would have a higher CBS score than would a randomly selected child in the non-clinical group. Sensitivity rates for cut scores ranged from .76-.83 and specificity rates ranged from .88-.95, meeting Glascoe's (2005) recommendation for screening instruments. The positive predictive value and negative predictive values were calculated for each cut score. The positive predictive value, which assesses the probability of obtaining a true positive result, ranged from .58 -.78 across age groups. The negative predictive value, which assesses the probability of obtaining a true negative result, ranged from .94 - .96 across age groups.

\section{Discussion}

The primary purpose of this study was to determine if the CBS could quickly and efficiently identify young children who may be at-risk for behavior disorders. In order to meet this goal, the 10-item CBS was designed as an instrument that was easy to administer, score, and interpret. The Flesh-Kincaid reading grade level was 3.9 and was simple enough for most parents to complete independently. Initial analyses found that parents of younger children endorsed behavioral items as being more frequent than parents of older children. This finding is consistent with longitudinal research which found a peak of behavior problems around age two that declines by age four and five (Hill, Degan, Calkins, \& Keane, 2006). From a developmental perspective, younger children may be more prone to externalizing behaviors, in part, because their ability to communicate displeasure through other means is limited (i.e., speech). Results from the age- 
specific cut offs generated by the ROC curve analyses identified higher cut scores for younger children which gradually decreased as the child aged (see Table 5). The age specific cut scores shown in Table 5 met recommended criteria for first-line screening instruments and had good sensitivity and specificity. These scores had excellent negative predictive value and adequate positive predictive value. Among those that had a negative screening test, the probability that a child did not have an externalizing behavior disorder ranged from $94 \%$ to $96 \%$, depending on the child's age.

Gender did not play a significant role in distinguishing scores in the clinical sample, but did exert a small effect size in the non-clinical sample. Although the option of creating separate cut scores by gender was considered, it was ultimately decided against doing so because of the absence of a gender effect for the clinical sample, the small effect size observed in the non-clinical sample, and previous research that suggests that externalizing profiles in preschoolers do not substantially vary across gender. Longitudinal research has found that the trajectory for externalizing behaviors for males and females are similar in preschool aged children (Beyer, Postert, Muller, Furniss, 2012; Hill, Degan, Calkins, and Keane, 2006). For example, Hill, Degan, Calkins, and Keane (2006) found that although reasons for membership in externalizing groups were different across genders, the trend in the developmental course across genders for preschool aged children was markedly similar. Age of the child also impacts the expression of an externalizing behavior disorder and this trend was also captured by the ECBS. Research has consistently found a higher frequency of externalizing behavior at younger ages, particularly ages two and three, which gradually declines as the child ages (Hill, Degan, Calkins, \& Keane, 2006; Miner \& Clarke-Stewart, 2008).

The factor structure of the ECBS was also tested to provide further evidence of the scale's validity. CFA results demonstrated that the two factor model originally identified in the non-clinical sample adequately fit the data for the clinical sample. In other words, this analysis provides further evidence that items are properly aligned with the correct latent variables (i.e., challenging behaviors and prosocial behaviors). 
NOT THE PUBLISHED VERSION; this is the author's final, peer-reviewed manuscript. The published version may be accessed by following the link in the citation at the bottom of the page.

The CBS fulfills an important need as first-line screener for externalizing behavior problems in very young children in poverty, who are a high risk group for the development of high-intensity stable behavior problems (Cote, Vaillancourt, LeBlanc, Nagin \& Tremblay, 2006; Fanti \& Henrich, 2010). The measure is short, simple to administer, easy to score and interpret, and has acceptable reliability and validity. Importantly, it is available at no cost to users and takes less than five minutes to administer, score, and interpret making it easy to implement at home, clinic, or hospital settings by a variety of health care professionals. A copy of ECBS short version, which includes the CBS only, is included in the manuscript and is free for use for qualified users (see Figure 3). Early behavior disorders are often not temporary and are linked to psychopathology later in life. Receiving intervention services early on may lessen the risk for poorer psychosocial outcomes and help prevent the development of later psychopathology. Thus, it is vitally important that children are screened for these disorders early and receive treatment if a behavior disorder is identified through a more comprehensive evaluation. For children who test at or above the cutoff scores on the CBS, a more thorough evaluation is recommended as there may be several different contributing factors to a child's behavior problems that will influence the choice of treatment (e.g., chaotic home environment, lack of supervision or parental attention, trauma, etc.). Although some young children do improve alone with the passage of time, many do not (Fanti \& Henrich, 2010; Poulou, 2015; Tyler-Merrick \& Church, 2013). Evidence-based programs are available that were designed specifically for very young children with behavior problems living in poverty (Fung \& Fox, 2014; Harris, Fox, \& Love, 2015)

\section{References}

Achenbach, T.M., \& Rescorla, L.A. (2000). Manual for the Child Behavior Checklist 1-5. Burlington: University of Vermont, Department of Psychiatry.

Bentler, P. M., \& Bonett, D. G. (1980). Significance tests and goodness of fit in the analysis of covariance structures. Psychological Bulletin, 88(3), 588-606. doi:10.1037/0033-2909.88.3.588

Beyer, T., Postert, C., Müller, J., \& Furniss, T. (2012). Prognosis and continuity of child mental health problems from preschool to primary

Journal of Child and Family Studies, Vol 25, No. 4 (April 2016): pg. 1076-1085. DOI. This article is (c) Springer and permission has been granted for this version to appear in e-

Publications@Marquette. Springer does not grant permission for this article to be further copied/distributed or hosted elsewhere without the express permission from Springer. 
NOT THE PUBLISHED VERSION; this is the author's final, peer-reviewed manuscript. The published version may be accessed by following the link in the citation at the bottom of the page.

school: Results of a four-year longitudinal study. Child Psychiatry \& Human Development, 43, 533-543. doi:10.1007/s10578-012-0282-5

Bringewatt, E. H., \& Gershoff, E. T. (2010). Falling through the cracks: Gaps and barriers in the mental health system for America's disadvantaged children. Children and Youth Services Review, 32, 1291-1299. doi:10.1016/j.childyouth.2010.04.021

Brown, W. M., \& Cudeck, R. (1993). Alternative ways of assessing model fit. In K.A. Bollen \& J. S. Long (Eds.), Testing structural equation models (pp. 445-455). Newbury Park, CA: Sage.

Butler, A. M. (2013). Cross-racial measurement equivalence of the Eyberg Child Behavior Inventory factors among low-income young African American and non-Latino white children. Assessment, 20, 484-495. doi: $10.1177 / 1073191111431341$.

Campbell, S. (2002). Behavior problems in preschool children: Clinical and developmental issues ( $2^{\text {nd }}$ ed.). New York: Guilford Press.

Carter, A. S., Briggs-Gowan, M., \& Davis, N. O. (2004). Assessment of young children's social-emotional development and psychopathology: Recent advances and recommendations for practice. Journal of Child Psychology and Psychiatry, 45, 109-134. doi:10.1046/j.00219630.2003.00316.x

Cote, S. M., Vaillancourt, T., LeBlanc, J. C., Nagin, D. S., \& Tremblay, R. E. (2006). The development of physical aggression from toddlerhood to pre-adolescence: A nationwide longitudinal study of Canadian children. Journal of Abnormal Child Psychology, 34, 71-85. doi:10.1007/s10802-005-9001-z

Egger, H. L., \& Angold, A. (2006). Common emotional and behavioral disorders in preschool children: Presentation, nosology, and epidemiology. Journal of Child Psychology and Psychiatry, 47(3-4), 313-337. doi:10.1111/j.1469-7610.2006.01618.x

Eyberg, S.M., \& Pincus, D. (1999). Eyberg Child Behavior Inventory and Sutter-Eyberg Student Behavior Inventory-Revised professional manual. Odessa, FL: Psychological Assessment Services.

Fanti, K. A., \& Henrich, C. C. (2010). Trajectories of pure and co-occurring internalizing and externalizing problems from age 2 to age 12 : Findings from the national institute of child health and human development study of early child care. Developmental Psychology, 46 (5), 1159-1175. doi:10.1037/a0020659

Feeney-Kettler, K. A., Kratochwill, T. R., Kaiser, A. P., Hemmeter, M. L. \& Kettler, R. J. (2010). Screening young children's risk for mental health

Journal of Child and Family Studies, Vol 25, No. 4 (April 2016): pg. 1076-1085. DOI. This article is (C) Springer and permission has been granted for this version to appear in ePublications@Marquette. Springer does not grant permission for this article to be further copied/distributed or hosted elsewhere without the express permission from Springer. 
NOT THE PUBLISHED VERSION; this is the author's final, peer-reviewed manuscript. The published version may be accessed by following the link in the citation at the bottom of the page.

problems: A review of four measures. Assessment for Effective Intervention, 35, 218-230. doi: 10.1177/1534508410380557

Feil, E. G., Walker, H., Severson, H., \& Ball, A. (2000). Proactive screening for emotional/behavioral concerns in Head Start preschools: Promising practices and challenges in applied research. Behavioral Disorders, 26, 13-25.

Fox, R. A., Keller, K. M., Grede, P. L., \& Bartosz, A. M. (2007). A mental health clinic for toddlers with developmental delays and behavior problems. Research in Developmental Disabilities, 28, 119-129. doi: $10.1016 /$ j.ridd.2006.02.001

Fung, M. P., \& Fox, R. A. (2014). The culturally-adapted Early Pathways program for young Latino children in poverty: A randomized controlled trial. Journal of Latina/O Psychology, 2, 131-145. doi: $10.1037 /$ lat0000019

Glascoe, F. P. (2005). Screening for developmental and behavioral problems. Mental Retardation and Developmental Disabilities Research Reviews, 11, 173-179. doi:10.1002/mrdd.20068

Harris, S. E., Fox, R.A., \& Love, J.R. (2015). Early Pathways therapy for young children in poverty: A randomized controlled trial. Counseling Outcome Research and Evaluation, 6, 3-17. doi: $10.1177 / 2150137815573628$

Hill, A. L., Degan, K. A., Calkins, S. D., \& Keane, S. P. (2006). Profiles of externalizing behavior problems for boys and girls across preschool: The roles of emotion regulation and inattention. Developmental Psychology, 42, 913-928. doi:10.1037/0012-1649.42.5.913

Holtz, C. A., \& Fox, R. A. (2012). Behavior problems in young children from low-income families: The development of a new screening tool. Infant Mental Health Journal, 33, 82-94. doi:10.1002/imhj.20341

Holtz, C. A., Fox, R. A., \& Meurer, J. R. (2015). Incidence of behavior problems in toddlers and preschool children from families living in poverty. Journal of Psychology, 149, 161-174. doi: 10.1080/00223980.2013.853020

Miner, J. L., \& Clarke-Stewart, K. (2008). Trajectories of externalizing behavior from age 2 to age 9: Relations with gender, temperament, ethnicity, parenting, and rater. Developmental Psychology, 44 (3), 771-786. doi:10.1037/0012-1649.44.3.771

Poulou, M. (2015). Emotional and behavioural difficulties in preschool. Journal of Child \& Family Studies, 24(2), 225-236. doi:10.1007/s10826-0139828-9

Journal of Child and Family Studies, Vol 25, No. 4 (April 2016): pg. 1076-1085. DOI. This article is (C) Springer and permission has been granted for this version to appear in ePublications@Marquette. Springer does not grant permission for this article to be further copied/distributed or hosted elsewhere without the express permission from Springer. 
Stevens, G. D., Seid, M., Pickering, T. A., \& Tsai, K. (2010). National disparities in the quality of a medical home for children. Maternal and Child Health Journal, 14(4), 580-589. doi:10.1007/s10995-009-04545

Tyler-Merrick, G., \& Church, J. (2013). The importance of effective behaviour screening in the early years. Emotional \& Behavioural Difficulties, 18(1), 77-87. doi:10.1080/13632752.2012.697747

van Oort, F. V. A., van der Ende, J., Wadsworth, M. E., Verhulst, F. C., \& Achenbach, T. M. (2011). Cross-national comparison of the link between socioeconomic status and emotional and behavior problems in youth. Social Psychiatry and Psychiatric Epidemiology, 46, 167-172. doi: 10.1007/s00127-010-0191-5

\section{Corresponding Author}

R. A. Fox, Department of Counselor Education and Counseling Psychology, Marquette University, P.O. Box 1881, Milwaukee WI 53201-1881, USA; Email: robert.fox@marquette.edu

\section{Co-Authors}

Sara E. Harris, Department of Counselor Education and Counseling Psychology, Marquette University, Milwaukee WI

Casey A. Holtz, Department of Psychology, Wisconsin Lutheran College, Milwaukee WI

Your Child... How often does the behavior occur?

\begin{tabular}{|l|l|l|c|c|}
\hline 1. Hits others & Often & Sometimes & $\begin{array}{c}\text { Almost } \\
\text { Never }\end{array}$ \\
\hline 2. Throws things at others & Often & Sometimes & $\begin{array}{c}\text { Almost } \\
\text { Never }\end{array}$ & $\begin{array}{c}\text { Almost } \\
\text { Never }\end{array}$ \\
\hline 3. Has temper tantrums & Often & Sometimes & $\begin{array}{c}\text { Almost } \\
\text { Never }\end{array}$ & 4. Breaks things \\
\hline
\end{tabular}


NOT THE PUBLISHED VERSION; this is the author's final, peer-reviewed manuscript. The published version may be accessed by following the link in the citation at the bottom of the page.

\begin{tabular}{|l|l|l|l|l|}
\hline 5. Is angry & Often & Sometimes & $\begin{array}{c}\text { Almost } \\
\text { Never }\end{array}$ & \\
\hline 6. Hurts others & Often & Sometimes & $\begin{array}{c}\text { Almost } \\
\text { Never }\end{array}$ & \\
\hline $\begin{array}{l}\text { 7. Takes toys away from } \\
\text { others }\end{array}$ & Often & Sometimes & $\begin{array}{c}\text { Almost } \\
\text { Never }\end{array}$ & \\
\hline 8. Bothers others & Often & Sometimes & $\begin{array}{c}\text { Almost } \\
\text { Never }\end{array}$ & \\
\hline $\begin{array}{l}\text { 9. Refuses to go to bed at } \\
\text { night }\end{array}$ & Often & Sometimes & $\begin{array}{c}\text { Almost } \\
\text { Never }\end{array}$ & \\
\hline 10. Kicks others & Often & Sometimes & $\begin{array}{c}\text { Almost } \\
\text { Never }\end{array}$ & \\
\hline
\end{tabular}

Clinician Note: Sum the columns after scoring each item according to the following scale: Often $=3$; Sometimes $=2 ;$ Almost Never $=1$

\begin{tabular}{|l|l|}
\hline Raw Score Challenging & \\
\hline Clinically Significant? & \\
\hline
\end{tabular}

\section{Interpretation a}

Clinical significance is reached if child's RAW score meets or exceeds the following cutoff scores:

$\begin{array}{lc}\text { Age } & \text { Cut Score } \\ 1 \text { year old } & 21 \\ 2 \text { years old } & 20 \\ 3 \text { years old } & 19 \\ 4 \text { years old } & 18 \\ 5 \text { years old } & 17\end{array}$

${ }^{a}$ Clinicians should move the interpretation section and copy it on the back of this page or a separate page to prevent caregivers from making their own unqualified interpretations. 
Figure 1. Confirmatory Factor Analysis of the Early Child Behavior Screen using Structural Equation Modeling (Standardized Solution).

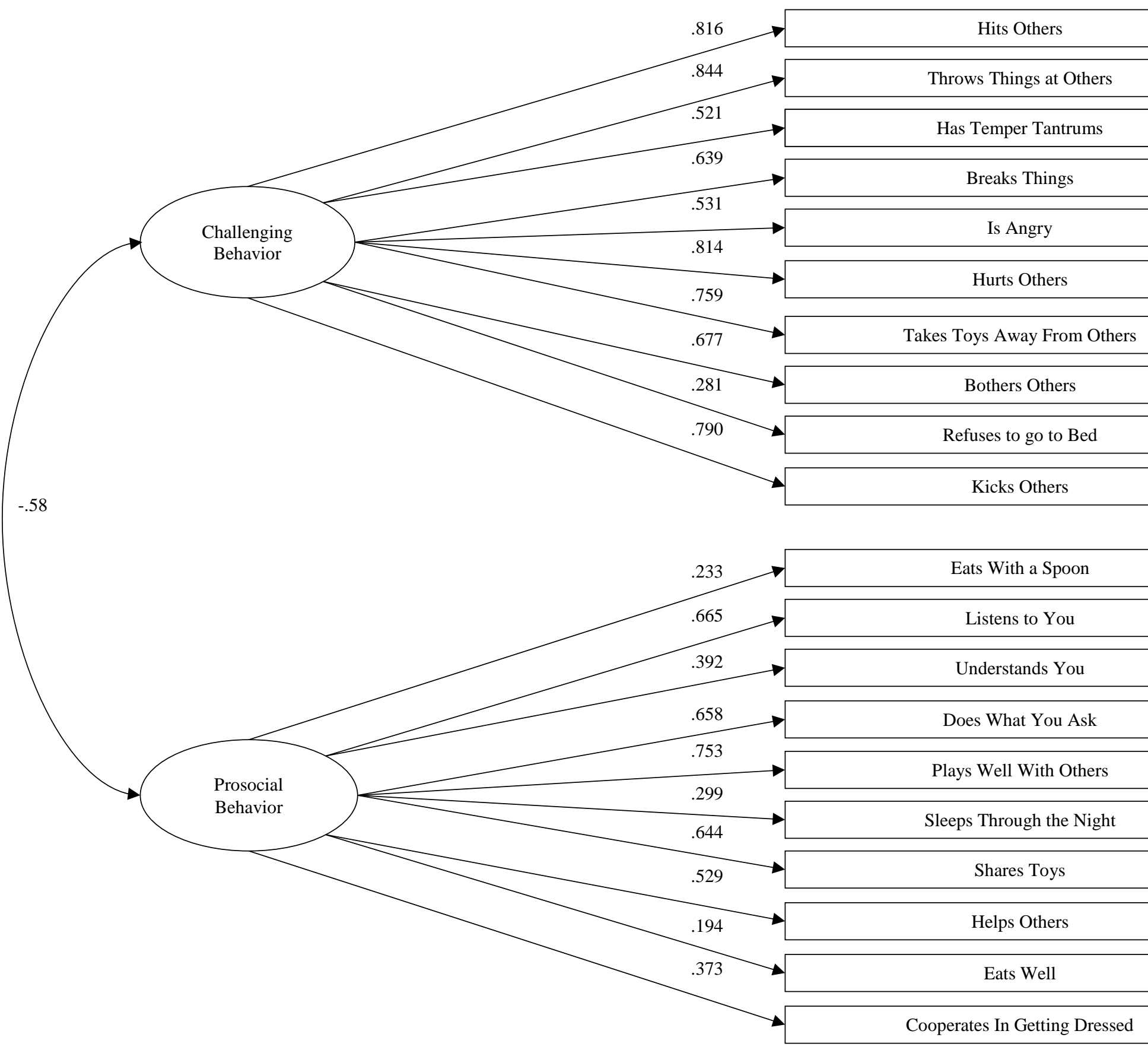

Journal of Child and Family Studies, Vol 25, No. 4 (April 2016): pg. 1076-1085. DOI. This article is (C) Springer and permission has been granted for this version to appear in $\mathrm{e}-$ Publications@Marquette. Springer does not grant permission for this article to be further copied/distributed or hosted elsewhere without the express permission from Springer. 
NOT THE PUBLISHED VERSION; this is the author's final, peer-reviewed manuscript. The published version may be accessed by following the link in the citation at the bottom of the page.

Figure 2. Mean Early Childhood Behavior Screen Challenging Behavior scale scores for ages $1,2,3,4$, and 5 in

the clinical and non-clinical groups.

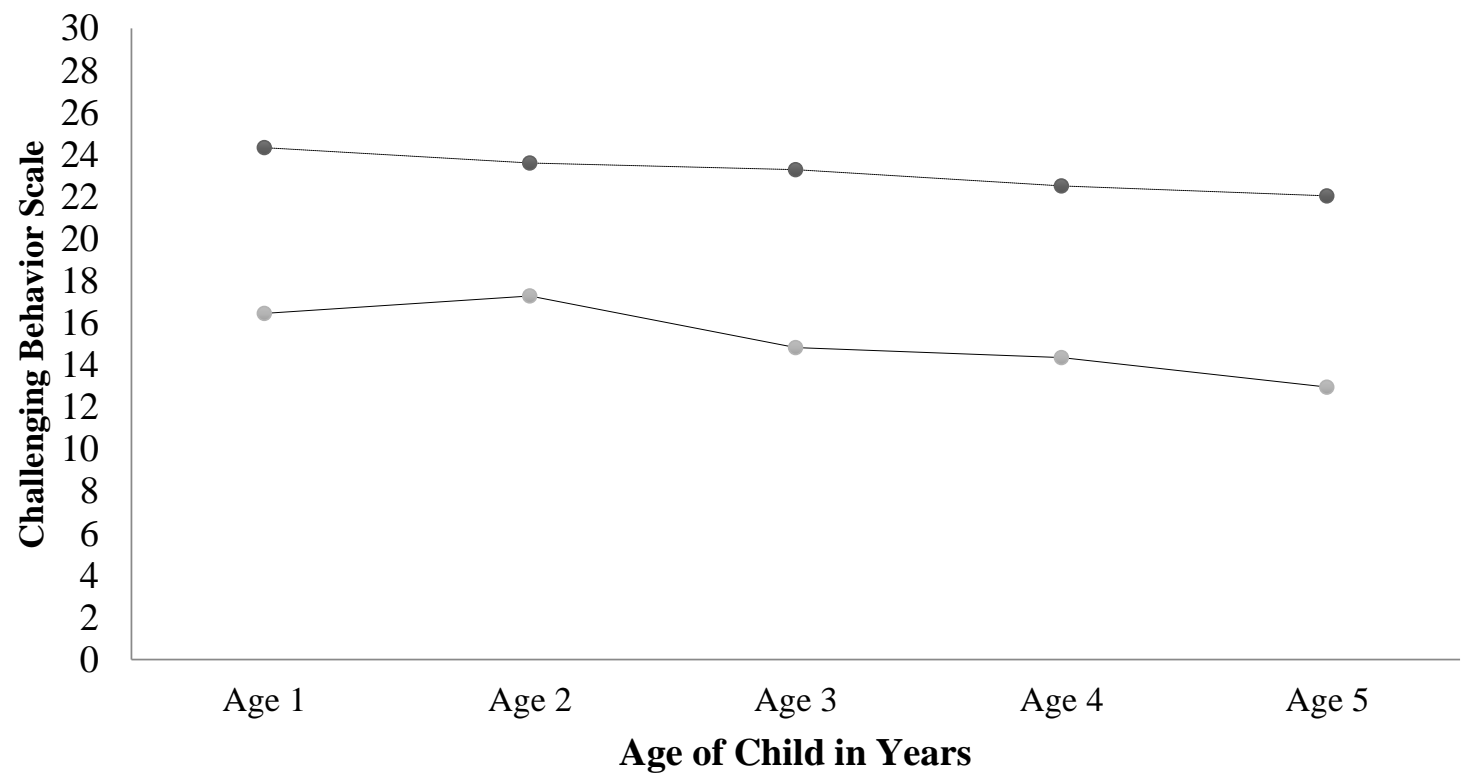

$\longrightarrow$ Clinical Group $\quad \longrightarrow$ Non-Clinical Group

Journal of Child and Family Studies, Vol 25, No. 4 (April 2016): pg. 1076-1085. DOI. This article is (C) Springer and permission has been granted for this version to appear in $\mathrm{e}-$ Publications@Marquette. Springer does not grant permission for this article to be further copied/distributed or hosted elsewhere without the express permission from Springer. 
NOT THE PUBLISHED VERSION; this is the author's final, peer-reviewed manuscript. The published version may be accessed by following the link in the citation at the bottom of the page.

Figure 3. Early Childhood Behavior Screen - Challenging Behavior Scale

The Early Childhood Behavior Screen - Challenging Behavior Scale

Name of Child:

Gender: M F

Date:

Clinician: Name of Caregiver:

Instructions: Listed below are common behaviors of toddlers and preschoolers. Think about your child's behavior over the past week, and rate how often you observed each behavior. Circle "often" if it happened at least daily, circle "sometimes" if it happened several times, and circle "almost never" if it rarely or never happens.

Journal of Child and Family Studies, Vol 25, No. 4 (April 2016): pg. 1076-1085. DOI. This article is (C) Springer and permission has been granted for this version to appear in ePublications@Marquette. Springer does not grant permission for this article to be further copied/distributed or hosted elsewhere without the express permission from Springer. 
NOT THE PUBLISHED VERSION; this is the author's final, peer-reviewed manuscript. The published version may be accessed by following the link in the citation at the bottom of the page.

Table 1

Demographics of Clinical and Non-Clinical Sample

\begin{tabular}{|c|c|c|c|c|c|c|c|c|c|}
\hline \multirow[b]{2}{*}{ Variable } & \multicolumn{4}{|c|}{ Clinical } & \multicolumn{4}{|c|}{ Non-Clinical } & \multirow[b]{2}{*}{$\begin{array}{l}\text { Effect } \\
\text { Size }\end{array}$} \\
\hline & $M$ & $S D$ & $n$ & $\%$ & $M$ & $S D$ & $n$ & $\%$ & \\
\hline Age of Child** & 2.74 & 1.02 & 428 & & 2.92 & 1.26 & 245 & & $.23^{\mathrm{a}}$ \\
\hline Gender** & & & & & & & & & $.15^{\mathrm{b}}$ \\
\hline Female & & & 133 & 31.1 & & & 115 & 46.9 & \\
\hline Male & & & 292 & 68.9 & & & 130 & 53.1 & \\
\hline Race*** & & & & & & & & & $.15^{\mathrm{b}}$ \\
\hline African American & & & 300 & 70.1 & & & 143 & 58.4 & \\
\hline Latino/a & & & 79 & 18.5 & & & 42 & 17.1 & \\
\hline Caucasian & & & 39 & 9.1 & & & 58 & 23.7 & \\
\hline Other & & & 10 & 2.3 & & & 2 & .8 & \\
\hline Age of Primary Caretaker* & 28.27 & 7.05 & & & 27.19 & 7.06 & & & $.15^{\mathrm{a}}$ \\
\hline
\end{tabular}

Journal of Child and Family Studies, Vol 25, No. 4 (April 2016): pg. 1076-1085. DOI. This article is (C) Springer and permission has been granted for this version to appear in $\mathrm{e}-$ Publications@Marquette. Springer does not grant permission for this article to be further copied/distributed or hosted elsewhere without the express permission from Springer. 
NOT THE PUBLISHED VERSION; this is the author's final, peer-reviewed manuscript. The published version may be accessed by following the link in the citation at the bottom of the page.

Table 2

Correlation, Means, and Standard Deviations of Items

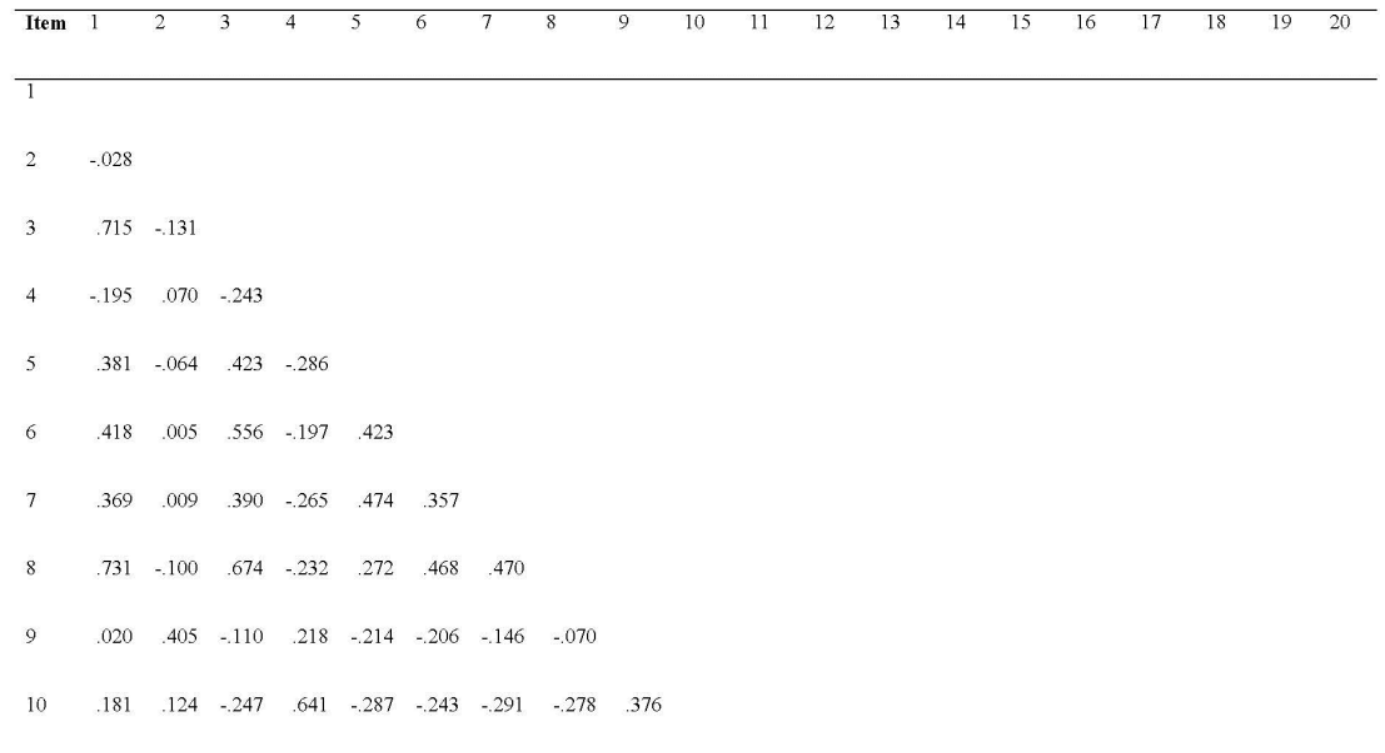

\begin{tabular}{|c|c|c|c|c|c|c|c|c|c|c|c|c|c|c|c|c|c|c|c|c|}
\hline 11 & .388 & .052 & -.424 & .407 & -.244 & -.323 & -.117 & -.433 & .212 & .298 & & & & & & & & & & \\
\hline 12 & -.129 & .256 & -249 & .104 & .032 & -.225 & -.042 & -.179 & .157 & .128 & .147 & & & & & & & & & \\
\hline 13 & .644 & .047 & .671 & -.252 & .389 & .418 & .363 & .594 & -.097 & -.141 & -.424 & -.062 & & & & & & & & \\
\hline 14 & -.306 & .081 & -.308 & .337 & -.265 & -.253 & -.262 & -.278 & .192 & .253 & .566 & .024 & -395 & & & & & & & \\
\hline 15 & -.203 & .318 & -.232 & .236 & -.123 & -.230 & -209 & -.205 & .385 & .351 & .408 & .106 & -.212 & .404 & & & & & & \\
\hline 16 & .527 & .024 & .499 & -.347 & .284 & .487 & .322 & .539 & -.007 & -.260 & -.376 & -.156 & .575 & -.314 & -.094 & & & & & \\
\hline 17 & .121 & .285 & -097 & .156 & .093 & -.065 & -.056 & $-.192^{\prime}$ & .160 & .062 & .028 & .218 & -.088 & .120 & .080 & -015 & & & & \\
\hline 18 & .111 & .117 & -.236 & .249 & -165 & -.246 & -138 & -.148 & .144 & .272 & .183 & .225 & -.221 & .196 & .178 & -.120 & .041 & & & \\
\hline 19 & .212 & -.095 & .185 & -.069 & .244 & .110 & .214 & .217 & -.082 & -.079 & -199 & -.296 & .163 & -132 & -.026 & .230 & -.063 & -.115 & & \\
\hline 20 & .648 & -.116 & .692 & -.255 & .325 & .533 & .347 & .651 & -.136 & -.269 & -.400 & -.212 & .559 & -.280 & -.262 & .555 & -.105 & -.132 & .183 & \\
\hline M & 2.53 & 2.66 & 2.42 & 1.90 & 2.68 & 1.96 & 2.47 & 2.06 & 2.42 & 1.88 & 2.03 & 2.43 & 2.51 & 1.86 & 2.16 & 2.35 & 2.43 & 2.31 & 2.23 & 2.08 \\
\hline SD & .63 & .58 & .67 & .57 & .53 & .75 & .59 & .72 & .59 & .52 & .60 & .73 & .61 & .59 & .60 & .68 & .66 & .67 & .74 & .79 \\
\hline
\end{tabular}
others.

Journal of Child and Family Studies, Vol 25, No. 4 (April 2016): pg. 1076-1085. DOI. This article is (C) Springer and permission has been granted for this version to appear in $\underline{\mathrm{e}-}$ Publications@Marquette.Springer does not grant permission for this article to be further copied/distributed or hosted elsewhere without the express permission from Springer. 
NOT THE PUBLISHED VERSION; this is the author's final, peer-reviewed manuscript. The published version may be accessed by following the link in the citation at the bottom of the page.

\section{Table 3}

Unstandardized and Standardized Parameter Estimates and Significance Levels for the Early Child Behavior Screen using Structural Equation Modeling

\begin{tabular}{|c|c|c|c|}
\hline Parameter Estimate & Unstandardized (SE) & Standardized & $p$ \\
\hline \multicolumn{4}{|l|}{ Measurement Model Estimates } \\
\hline \multicolumn{4}{|l|}{ Challenging Behavior Factor } \\
\hline Hits Others (X1) & 1.000 & 0.816 & .000 \\
\hline Throws Things (X2) & $1.034(0.048)$ & 0.844 & .000 \\
\hline Has Temper Tantrums (X3) & $0.639(0.072)$ & 0.521 & .000 \\
\hline Breaks Things (X4) & $0.783(0.056)$ & 0.639 & .000 \\
\hline Is Angry (X5) & $0.650(0.063)$ & 0.531 & .000 \\
\hline Hurts Others (X6) & $0.998(0.050)$ & 0.814 & .000 \\
\hline Takes Toys from Others (X7) & $0.931(0.053)$ & 0.759 & .000 \\
\hline Bothers Others (X8) & $0.830(0.056)$ & 0.677 & .000 \\
\hline Refuses to go to Bed (X9) & $0.345(0.066)$ & 0.281 & .000 \\
\hline Kicks Others (X10) & $0.968(0.047)$ & 0.790 & .000 \\
\hline \multicolumn{4}{|l|}{ Prosocial Behavior Factor } \\
\hline Eats with a Spoon (X11) & 1.000 & 0.233 & .002 \\
\hline Listens to you (X12) & $2.852(0.925)$ & 0.665 & .000 \\
\hline Understands You (X13) & $1.682(0.569)$ & 0.392 & .000 \\
\hline Does What you Ask (X14) & $2.824(0.933)$ & 0.658 & .000 \\
\hline
\end{tabular}

Journal of Child and Family Studies, Vol 25, No. 4 (April 2016): pg. 1076-1085. DOI. This article is (C) Springer and permission has been granted for this version to appear in ePublications@Marquette. Springer does not grant permission for this article to be further copied/distributed or hosted elsewhere without the express permission from Springer. 
NOT THE PUBLISHED VERSION; this is the author's final, peer-reviewed manuscript. The published version may be accessed by following the link in the citation at the bottom of the page.

\begin{tabular}{rrrr}
\hline Plays well with Others (X15) & $3.227(1.073)$ & 0.753 & .000 \\
Sleeps Through the Night (X16) & $1.280(0.413)$ & 0.299 & .000 \\
Shares Toys (X17) & $2.761(0.924)$ & 0.644 & .000 \\
Helps Others (X18) & $2.269(0.747)$ & 0.529 & .000 \\
Eats Well (X19) & $0.834(0.355)$ & 0.194 & .004 \\
Cooperates in Getting Dressed (X20) & $1.599(0.521)$ & 0.373 & .000 \\
Structural Model & & & .000 \\
Prosocial with Challenging Factor & $-0.110(0.037)$ & & \\
\hline
\end{tabular}

Journal of Child and Family Studies, Vol 25, No. 4 (April 2016): pg. 1076-1085. DOI. This article is (C) Springer and permission has been granted for this version to appear in $\mathrm{e}-$ Publications@Marquette. Springer does not grant permission for this article to be further copied/distributed or hosted elsewhere without the express permission from Springer. 
NOT THE PUBLISHED VERSION; this is the author's final, peer-reviewed manuscript. The published version may be accessed by following the link in the citation at the bottom of the page.

\section{Table 4}

Descriptive Data for the Early Childhood Behavior Screen's Challenging Behavior Scale

Clinical Sample Non-Clinical Sample $\quad$ Mean Difference $\quad$ Effect Size (d)

\begin{tabular}{|c|c|c|c|c|}
\hline Overall Score & 23.29 & 15.24 & 8.05 & 2.36 \\
\hline$S D$ & 3.41 & 3.41 & & \\
\hline$n$ & 428 & 245 & & \\
\hline Range & $12-30$ & $10-26$ & & \\
\hline Males & 23.46 & 15.65 & 7.81 & 2.34 \\
\hline$S D$ & 3.15 & 3.51 & & \\
\hline$n$ & 295 & 130 & & \\
\hline Range & $12-30$ & $10-26$ & & \\
\hline Females & 22.92 & 14.78 & 8.14 & 2.52 \\
\hline$S D$ & 3.23 & 3.23 & & \\
\hline$n$ & 133 & 115 & & \\
\hline Range & $13-30$ & $10-24$ & & \\
\hline Age One & 24.33 & 16.46 & 7.87 & 2.31 \\
\hline$S D$ & 2.91 & 3.82 & & \\
\hline$n$ & 42 & 48 & & \\
\hline Range & $13-30$ & $10-25$ & & \\
\hline Age Two & 23.60 & 17.28 & 6.32 & 1.63 \\
\hline
\end{tabular}

Journal of Child and Family Studies, Vol 25, No. 4 (April 2016): pg. 1076-1085. DOI. This article is (C) Springer and permission has been granted for this version to appear in ePublications@Marquette.Springer does not grant permission for this article to be further copied/distributed or hosted elsewhere without the express permission from Springer. 
NOT THE PUBLISHED VERSION; this is the author's final, peer-reviewed manuscript. The published version may be accessed by following the link in the citation at the bottom of the page.

\begin{tabular}{|c|c|c|c|c|}
\hline SD & 4.41 & 3.24 & & \\
\hline $\mathrm{n}$ & 143 & 40 & & \\
\hline Range & $12-30$ & $12-26$ & & \\
\hline Age Three & 23.28 & 14.83 & 8.45 & 2.37 \\
\hline$S D$ & 4.13 & 2.88 & & \\
\hline$n$ & 147 & 60 & & \\
\hline Range & $14-30$ & $10-22$ & & \\
\hline Age Four & 22.51 & 14.35 & 8.16 & 1.98 \\
\hline$S D$ & 4.97 & 3.06 & & \\
\hline$n$ & 73 & 77 & & \\
\hline Range & $12-30$ & $10-22$ & & \\
\hline Age Five & 22.04 & 12.95 & 9.09 & 2.34 \\
\hline$S D$ & 4.90 & 2.50 & & \\
\hline$n$ & 23 & 20 & & \\
\hline Range & $14-30$ & $10-19$ & & \\
\hline
\end{tabular}

Note. Mean difference and effect size statistic is between the clinical and non-clinical groups in their respective demographic categories in the table.

Journal of Child and Family Studies, Vol 25, No. 4 (April 2016): pg. 1076-1085. DOI. This article is (C) Springer and permission has been granted for this version to appear in ePublications@Marquette.Springer does not grant permission for this article to be further copied/distributed or hosted elsewhere without the express permission from Springer. 
NOT THE PUBLISHED VERSION; this is the author's final, peer-reviewed manuscript. The published version may be accessed by following the link in the citation at the bottom of the page.

Table 5

ROC Curve Analysis Results for Early Childhood Behavior Screen's Challenging Behavior Scale

\begin{tabular}{cccccccc}
\hline Age & AUC & $95 \%$ CI & Cut Score & Sensitivity & Specificity & PPV & NPV \\
& & & & & & & \\
\hline 1 & .90 & $.84-.97$ & 21 & .81 & .90 & .64 & .95 \\
2 & .87 & $.82-.93$ & 20 & .76 & .88 & .58 & .94 \\
3 & .95 & $.93-.98$ & 19 & .80 & .93 & .71 & .95 \\
4 & .91 & $.86-.96$ & 18 & .80 & .88 & .59 & .95 \\
5 & .97 & $.93-1.00$ & 17 & .83 & .95 & .78 & .96
\end{tabular}

Note: The notation AUC refers to area under the curve. The notation CI refers to the confidence interval for the AUC. The notation PPV refers to positive predicative value. The Notation NPV refers to negative predictive value. PPV and NPV was calculated with an estimated prevalence rate for behavior disorders set at $18 \%$.

Journal of Child and Family Studies, Vol 25, No. 4 (April 2016): pg. 1076-1085. DOI. This article is (C) Springer and permission has been granted for this version to appear in $\underline{\text { e- }}$ Publications@Marquette. Springer does not grant permission for this article to be further copied/distributed or hosted elsewhere without the express permission from Springer. 